\title{
Spectrophotometric Determination of Titanium(IV) by Using 3,4-Dihydroxybenzaldehydeisonicotinoyl- hydrazone(3,4- DHBINH) as a Chromogenic Agent
}

\author{
LAKSHMI NARAYANA SUVARAPU*, YOUNG-KYO SEO and SUNG-OK BAEK \\ School of Environmental Engineering, Yeungnam University, Gyeongsan-si, \\ Republic of Korea - 712749 \\ lakshminarayana_chem@rediffmail.com
}

Received 6 May 2012; Accepted 19 May 2012

\begin{abstract}
Dihydroxybenzaldehydeisonicotinoylhydrazone(3,4-DHBINH) was prepared, characterized with spectral analyses and used for developing a new method for the simple, sensitive and rapid spectrophotometric determination of titanium(IV) which gives maximum absorbance at wave length $370 \mathrm{~nm}$. The metal ion gives a yellow colored complex with 3,4-DHBINH in acetate buffer of pH 3.5 with 1:2 (metal: ligand) composition. The method obeys Beer's law in the range 0.5-4.25 ppm of titanium(IV). The molar absorptivity and Sandell's sensitivity were found to be $1.489 \times 10^{4} \mathrm{~L} \mathrm{~mol}^{-1} \mathrm{~cm}^{-1}$ and $0.003217 \mu \mathrm{g} \mathrm{cm}^{-2}$, respectively at $370 \mathrm{~nm}$. The correlation co-efficient of the Ti(IV)-3,4DHBINH complex was 1.00125 which indicated an excellent linearity between the two variables. The repeatability of the method was checked by finding the relative standard deviation (RSD) as $0.347 \%(n=5)$ and its detection limit $0.0053 \mu \mathrm{g} \mathrm{mL}{ }^{-1}$ of titanium(IV). The interfering effect of various cations and anions were also studied.
\end{abstract}

Keywords: Chromogenic agent, Titanium(IV), Spectrophotometry, 3,4-DHBINH

\section{Introduction}

Metallic titanium is well known for its excellent corrosion resistance, having ability to withstand attack by dilute Sulphuric acid and hydrochloric acid or even moist chlorine. It is as strong as steel, but much lighter, yet it is heavier than aluminium and twice as strong. These properties make titanium highly resistant to the usual kinds of metal fatigue ${ }^{1}$. Approximately 95\% of titanium production is consumed in the form of titanium dioxide. Titanium alloys are principally used for aircrafts and missiles, where light weight strength and ability to withstand extremes of temperature are important. Its capacity for joining with bone and other tissue-Osseo integration makes it suitable for medical applications, such as total replacement of arthritis hips, knee joints, facial treatment and dental implants ${ }^{2}$. Titanium exists in nature in its most stable and common oxidation state as titanium (IV). Titanium dioxide is extensively used as a white pigment in printing ink, ceramics and cosmetics. Ferro titanium is used as scavenger to remove oxygen, hydrogen and nitrogen in steel industry. The pure titanium resembles stainless steel. Many organic compounds of titanium such as phthalates, oxalates, tetraethylate and butyltitanate are widely synthesized and used extensively. Barium 
titanate shows remarkable ferro electric behavior. For the determination of titanium(IV) in micro levels, there are several frequently adopted methods using analytical techniques, such as AAS, ICP-AES, ICP-MS, x-ray fluorescence spectroscopy, spectrophotometry and such other techniques. Among these, spectrophotometric methods are preferred because they are cheaper and easier to handle, with comparable sensitivity.

A thorough literary survey has revealed that a few number of hydrazones are available for the spectrophotometric and extractive spectrophotometric determination of titanium(IV) ${ }^{3-8}$. It indicates that the potentiality of hydrazones is not fully utilized. Hence 3,4-dihydroxybenzaldehydeisonicotinoylhydrazone(3,4-DHBINH) is tried for the development of a simple, selective and sensitive spectrophotometric method for titanium(IV). In the present investigation, we studied the reactivity of 3,4-DHBINH with titanium(IV) and the findings are reported in terms of its $\mathrm{pH}$, maximum absorbance, molar absorptivity and stoichiometry, which provide the basis for judging the potential utility of 3,4-DHBINH as a chromogenic reagent for titanium(IV).

\section{Experimental}

3,4-DHBINH was synthesized and recrystalized as reported by Sah et $a l^{9}$. Equimolar quantities of 3,4-dihydroxybenzaldehyde (dissolved in alcohol) and isonicotinoylhydrazide (dissolved in water) were taken in a $500 \mathrm{~mL}$ standard flask and refluxed for 2-3 h. The contents were cooled and then filtered. The product (Scheme 1.) obtained was washed with aqueous methanol and finally recrystallized from rectified spirit. The purity of the reagent was checked by TLC and melting point analysis (m.p. $218-219{ }^{\circ} \mathrm{C}$ ). It is evident from IR spectral data that, $\mathrm{C}=\mathrm{N}$ group is present in the compound because the peak appears at $1600 \mathrm{~cm}^{-1} . \mathrm{C}=\mathrm{O}$ (Stretching) amide peak appears at $1656.9 \mathrm{~cm}^{-1} .-\mathrm{OH}$ group peaks appears at $3484.6 \mathrm{~cm}^{-1}$, -NH peak appears at $3245 \mathrm{~cm}^{-1}$. From the above data it is confirmed the formation of 3,4- DHBINH

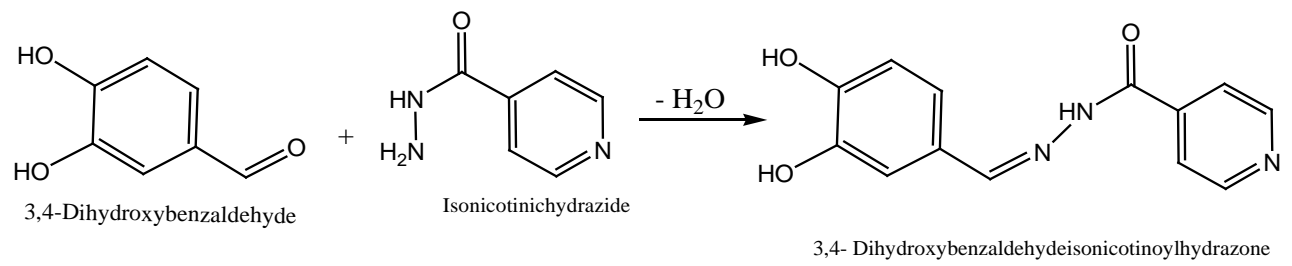

Scheme 1. Formation of 3,4-DHBINH

\section{Preparation of a stock solution of titanium(IV)}

The stock solution $\left(1.0 \times 10^{-2} \mathrm{M}\right)$ was prepared by dissolving $0.885 \mathrm{~g}$ of potassiumtitanyloxalate (M.Wt. $354.17 \mathrm{~g}$ ) in $15 \mathrm{~mL}$ of $\mathrm{H}_{2} \mathrm{SO}_{4}$ and made up to the mark with double distilled water in $250 \mathrm{~mL}$ standard flask and standardized by gravimetrically $^{10}$. Lower concentrations of the metal ion are obtained by suitable dilution of the stock solution.

\section{Recommended procedure}

An aliquot of metal ion solution, $4.0 \mathrm{~mL}$ of buffer solution $(\mathrm{pH}=3.5), 1.0 \mathrm{~mL}$ of 3,4-DHBINH solution of the required concentration were taken in a $10.0 \mathrm{~mL}$ standard flask and the contents were made up to the mark with distilled water. The absorbance of the solution recorded against the reagent blank, prepared under the same conditions. 


\section{Buffer solutions}

Solutions of 1.0 M sodium acetate and 1.0 M acetic acid were prepared in double distilled water. Suitable portions of these solutions were mixed to get the desired $\mathrm{pH}$ of the solution.

\section{Apparatus}

A recording spectrophotometer (model Hitachi U - 2000) was employed in photometric studies. A Perkin - Elmer 2380 atomic absorption spectro -photometer was employed for the comparison of the results of samples. A digital pH meter (model Elico LI - 129) was used for measuring the $\mathrm{pH}$ of solutions.

\section{Results and Discussion}

Titanium(IV) reacts with 3,4-DHBINH and gives a yellow colored complex. The complex has maximum absorbance at $370 \mathrm{~nm}$. The effect of various factors like $\mathrm{pH}$, concentration of reagent, stability and foreign ions on the determination of titanium(IV) have been studied for developing a highly sensitive spectrophotometric determination of titanium(IV).

\section{Absorption spectra}

The absorption spectrum of Ti(IV)-3,4-DHBINH complex was recorded against the reagent blank. Similarly the absorption spectrum of the reagent (3,4-DHBINH) was recorded against the solvent blank. The absorption spectra of both the complex and reagent are shown in Figure 1. From the absorption spectra it is clear that the complex and reagent have shown maximum absorptions at $370 \mathrm{~nm}$ and $340 \mathrm{~nm}$, respectively. The reagent has minimum absorbance at the maximum absorbance of the complex. The reagent absorbance at the maximum absorbance of metal complex was further suppressed using suitable concentration of reagent as blank. Hence further absorbance measurements were made at $370 \mathrm{~nm}$.

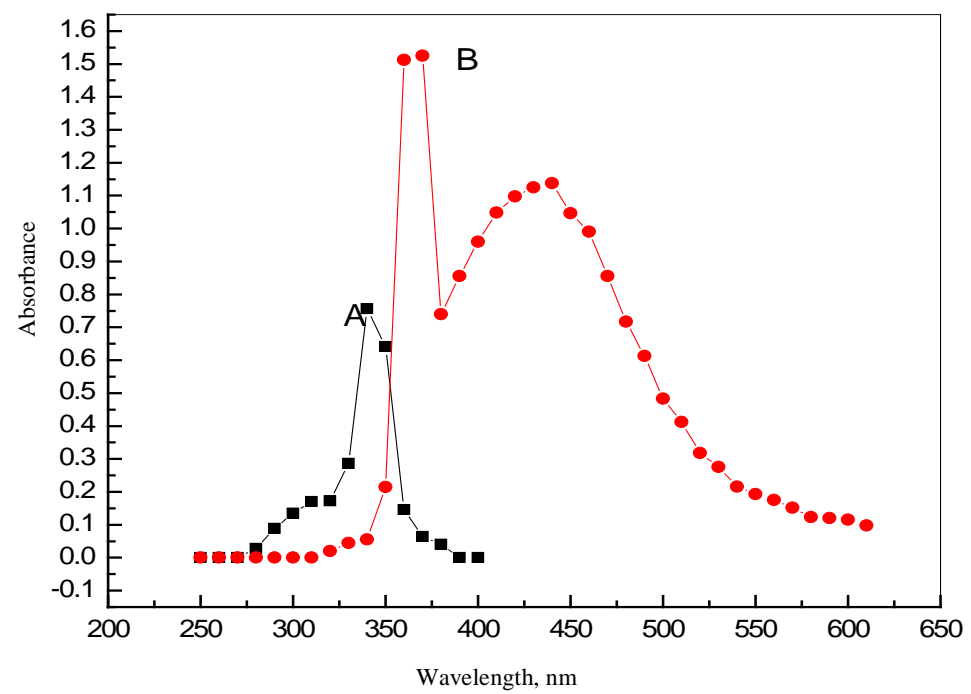

Figure 1. (A) Absorption spectrum of 3,4-DHBINH vs. blank (B) Absorption spectrum of Ti(IV)-3,4-DHBINH complex vs. blank $\mathrm{Ti}(\mathrm{IV})=1.0 \mathrm{~mL}$ of $1.0 \times 10^{-4} \mathrm{M}, 3,4-\mathrm{DHBINH}=$ $1.0 \mathrm{~mL}$ of $1.0 \times 10^{-3} \mathrm{M}$ and $\mathrm{pH}=3.5$ 


\section{Effect of $p H$}

The effect of pH on the formation of Ti(IV)-3,4-DHBINH complex was studied, in order to find a suitable $\mathrm{pH}$ that can be adopted in the determination of titanium(IV). In this process, a series of solutions containing $1.0 \mathrm{~mL}$ of $1.0 \times 10^{-4} \mathrm{M}$ titanium(IV) solution, $4.0 \mathrm{~mL}$ of various $\mathrm{pH}(1.0-6.5)$ buffer solutions and $1.0 \mathrm{~mL}$ of $1.0 \times 10^{-3} \mathrm{M}$ of 3, 4-DHBINH solution were prepared. Each solution was taken into $10.0 \mathrm{~mL}$ standard flask and made upto the mark with double distilled water. The reagent blanks were also prepared in a similar way without titanium(IV) solution. The absorbances of all the solutions were measured at $370 \mathrm{~nm}$ against their corresponding reagent blanks.The absorbance of the complex increases as the $\mathrm{pH}$ increases from 1.0 to 3.0 and remain constant in the $\mathrm{pH}$ range 3.0-4.0. However it is decreased from 4.0. Hence, sodium acetate-acetic acid buffer was used for further studies considering 3.5 as optimum $\mathrm{pH}$.

\section{Effect of reagent concentration}

The effect of reagent concentration on the formation of the Ti(IV)-3,4-DHBINH complex has been studied by keeping the concentration of metal ion solution $1.0 \times 10^{-4} \mathrm{M}$ and the 3,4-DHBINH solution containing different concentrations ranging from $1.0 \times 10^{-4}-20.0 \times 10^{-4} \mathrm{M}$ in order to get the maximum color formation. The colored solutions were collected into $10.0 \mathrm{~mL}$ standard flasks and made up to the mark with double distilled water. The absorbances of these solutions were measured at $370 \mathrm{~nm}$ against their corresponding blanks. The results clearly indicate that a ten fold molar $\left(10.0 \times 10^{-4} \mathrm{M}\right)$ excess of reagent to that of the metal ion was sufficient for maximum color development of the Ti(IV)-3,4-DHBINH complex. Hence a ten fold molar excess of the reagent was maintained for further studies.

\section{Applicability of Beer's law}

Known aliquots of $10.0 \mathrm{~mL}$ solutions, each containing constant volumes of $4.0 \mathrm{~mL}$ of sodium acetate-acetic acid buffer $(\mathrm{pH} 3.5), 1.0 \mathrm{~mL}$ of $10.0 \times 10^{-4} \mathrm{M}$ reagent and $1.0 \mathrm{~mL}$ of titanium(IV) solution $\left(0.1044 \times 10^{-4}-1.0445 \times 10^{-4} \mathrm{M}\right)$ containing $0.5-5.0 \mu \mathrm{g} \mathrm{mL}^{-1}$ were prepared. The absorbances of these solutions were measured at $370 \mathrm{~nm}$. A graph plotted between the amount of titanium(IV) and its absorbance is shown in Figure 2. It can be observed from the graph that a linear plot passing through the origin obeys Beer's law in the range $0.50-4.25 \mu \mathrm{g} \mathrm{mL}^{-1}$ of titanium(IV).

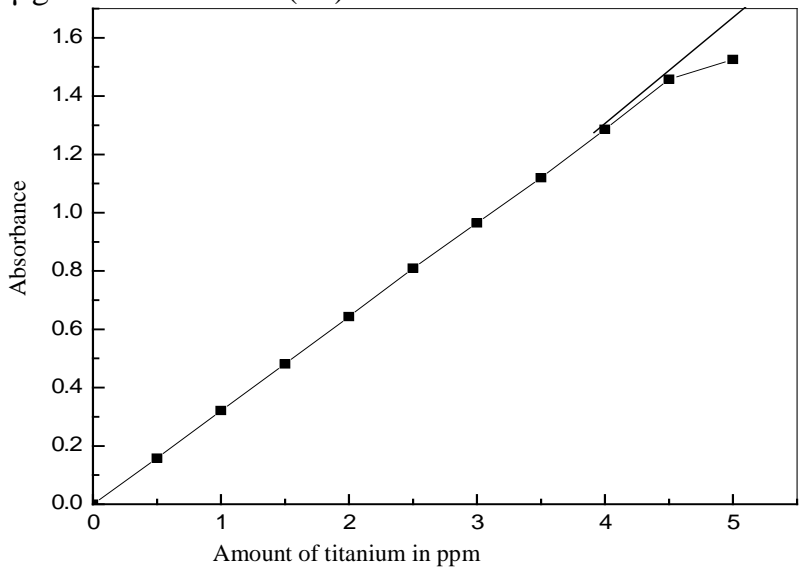

Figure 2. Applicability of Beer's law to Ti(IV) - 3, 4-DHBINH complex: Ti(IV) $=1.0 \mathrm{~mL}$ of $0.1044 \times 10^{-4}-1.0445 \times 10^{-4} \mathrm{M}, 3,4-\mathrm{DHBINH}=1.0 \mathrm{~mL}$ of $10.0 \times 10^{-4} \mathrm{M}, \mathrm{pH}=3.5$ and $\lambda_{\max }=370 \mathrm{~nm}$ 


\section{Molar absorptivity, Sandell's sensitivity and correlation co-efficient}

The molar absorptivity of the complex was calculated to be $1.489 \times 10^{4} \mathrm{~L} \mathrm{~mol}^{-1} \mathrm{~cm}^{-1}$ and Sandell's sensitivity of the complex obtained from Beer's law data was $0.0032 \mu \mathrm{g} \mathrm{cm}{ }^{-2}$ at $370 \mathrm{~nm}$ and $1.399 \times 10^{4} \mathrm{~L} \mathrm{~mol}^{-1} \mathrm{~cm}^{-1}$ and $0.0034 \mu \mathrm{g} \mathrm{cm}{ }^{-2}$ at $430 \mathrm{~nm}$, respectively. The correlation coefficient of the Ti(IV)-3,4-DHBINH complex was 1.0012, which indicates an excellent linearity between the two variables.

\section{Ringbom plot for the Ti(IV)-3,4-DHBINH complex}

A Ringbom plot (Figure 3) is an established standard method adapted to know the optimum range of concentration for a system that obeys Beer's law. A Ringbom plot was drawn between $\log \mathrm{C}$ of $\mathrm{Ti}(\mathrm{IV})$ and (1-T), where $\mathrm{T}$ is transmittance. The plot has sigmoid shape with a linear segment at intermediate absorbance values (0.643-1.286) and concentration values $\left(2.0-4.0 \mu \mathrm{g} \mathrm{mL}^{-1}\right)$. The slope of the Ringbom plot was 0.680 . Hence the ratio between the relative error in concentration and photometric error was found to be 3.3867 for one percent photometric error, $\Delta \mathrm{P}=0.01$. Hence the relative error in the concentration was 0.0338 .

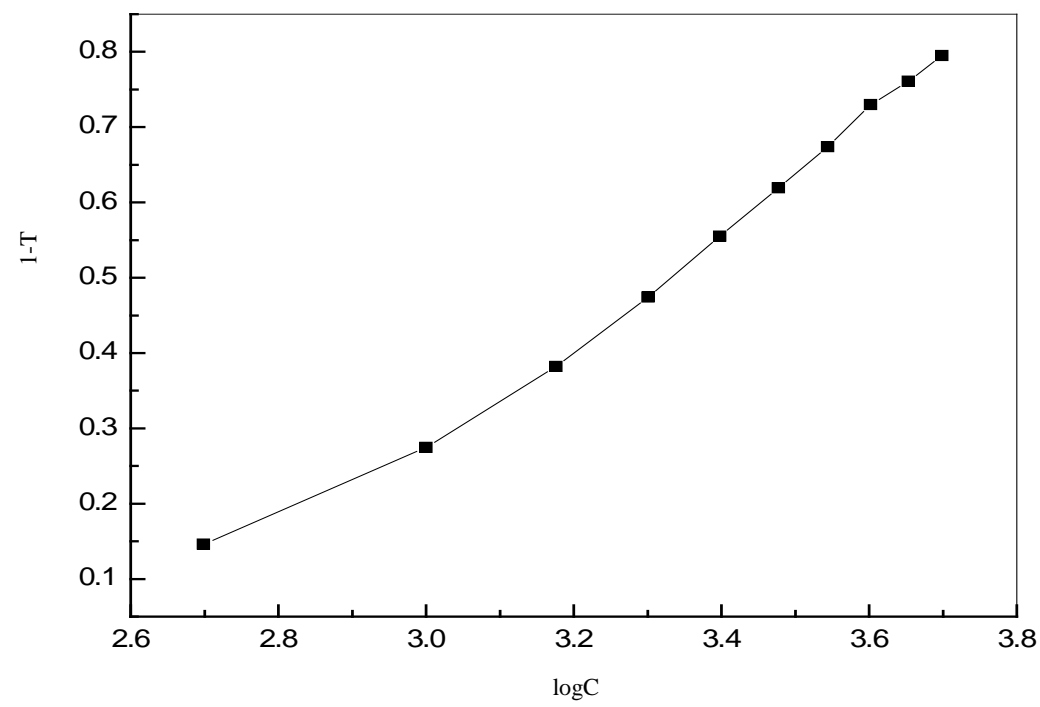

Figure 3. Ringbom plot of Ti(IV)-3,4-DHBINH complex: $\mathrm{Ti}(\mathrm{IV})=500-5000 \mu \mathrm{g} \mathrm{L}^{-1}$, $3,4-\mathrm{DHBINH}=1.0 \mathrm{~mL}$ of $10.0 \times 10^{-4} \mathrm{M}, \mathrm{pH}=3.5$ and $\lambda_{\max }=370 \mathrm{~nm}$

Precision, accuracy and detection limit of the method

To assess the precision of the method, determinations were carried out with different concentrations of titanium(IV) under optimum conditions. The standard deviation was found to be not more than 0.0023 and the relative standard deviation was less than $0.347 \%$. It is evident from these results that the method is precise, besides being accurate. The detection limit was determined as $0.0053 \mu \mathrm{g} \mathrm{mL}{ }^{-1}$ of titanium(IV).

\section{Composition of the Ti(IV)-3,4-DHBINH complex}

Job's method of continuous variation, molar ratio method and Asmus' methods were employed to elucidate the composition of the complex. 


\section{Job's method of continuous variation}

Equimolar solutions $\left(1.0 \times 10^{-4} \mathrm{M}\right)$ of titanium(IV) and 3,4-DHBINH was prepared. The metal and reagent solutions were mixed in different proportions, keeping the total volume of metal and ligand constant at $1.2 \mathrm{~mL}$ In each case, $4.0 \mathrm{~mL}$ of sodium acetate-acetic acid buffer (pH 3.5) was added to the mixture and the total volume of the solution was made up to $10.0 \mathrm{~mL}$ with double distilled water. The absorbances of all the solutions were recorded at $370 \mathrm{~nm}$ against their reagent blanks. The corresponding graph (Figure 4) drawn between absorbance and $V_{M}$ $/ \mathrm{V}_{\mathrm{L}}+\mathrm{V}_{\mathrm{M}}$ (where $\mathrm{V}_{\mathrm{L}}$ and $\mathrm{V}_{\mathrm{M}}$ are the volumes of the reagent and the metal, respectively) indicates that one mole of titanaium(IV) reacts with two moles of ligand and the composition of metal to ligand complex as 1:2. The composition of the complex was further confirmed by Molar ratio method (Figure 5) and Asmus method (Figure 6).

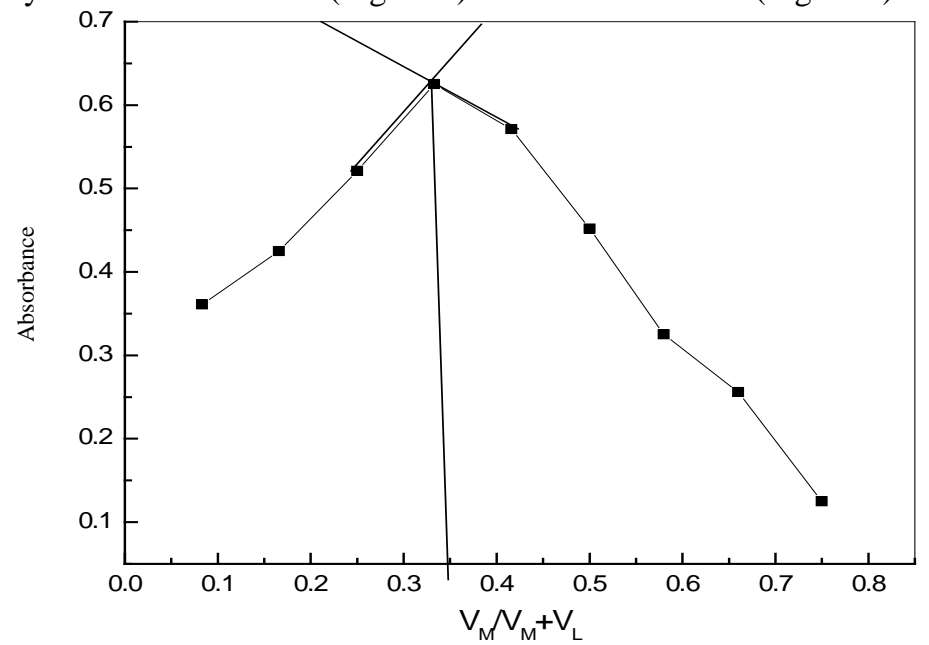

Figure 4. Job's method of continuous variation: $[\mathrm{Ti}(\mathrm{IV})=3,4-\mathrm{DHBINH}]=1.0 \mathrm{~mL}$ of $1.0 \times 10^{-4} \mathrm{M}, \mathrm{pH}=3.5$ and $\lambda_{\max }=370 \mathrm{~nm}$

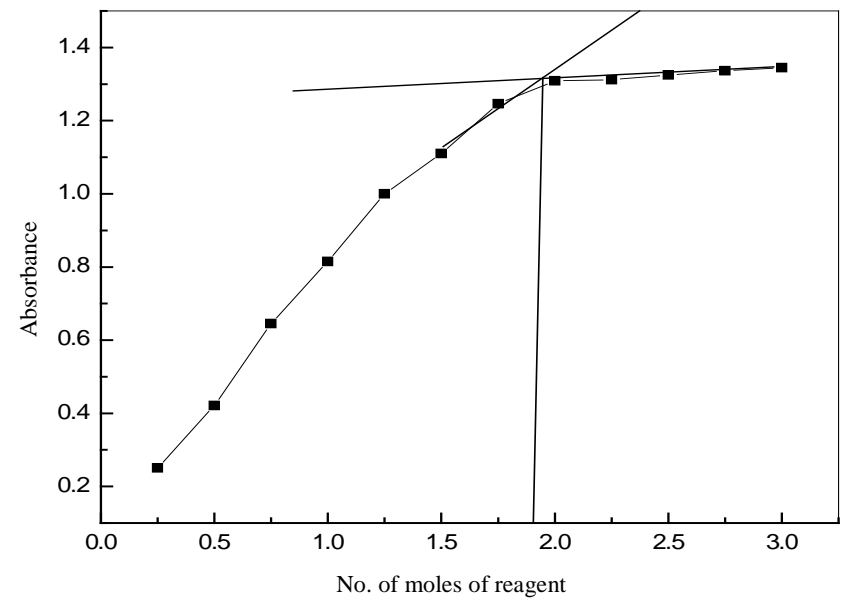

Figure 5. Molar ratio method: $\mathrm{Ti}(\mathrm{IV})=1.0 \mathrm{~mL}$ of $1.0 \times 10^{-4} \mathrm{M}, 3,4-\mathrm{DHBINH}=1.0 \mathrm{~mL}$ of $\left(0.25 \times 10^{-4}-3.0 \times 10^{-4} \mathrm{M}\right), \mathrm{pH}=3.5$ and $\lambda_{\max }=370 \mathrm{~nm}$ 


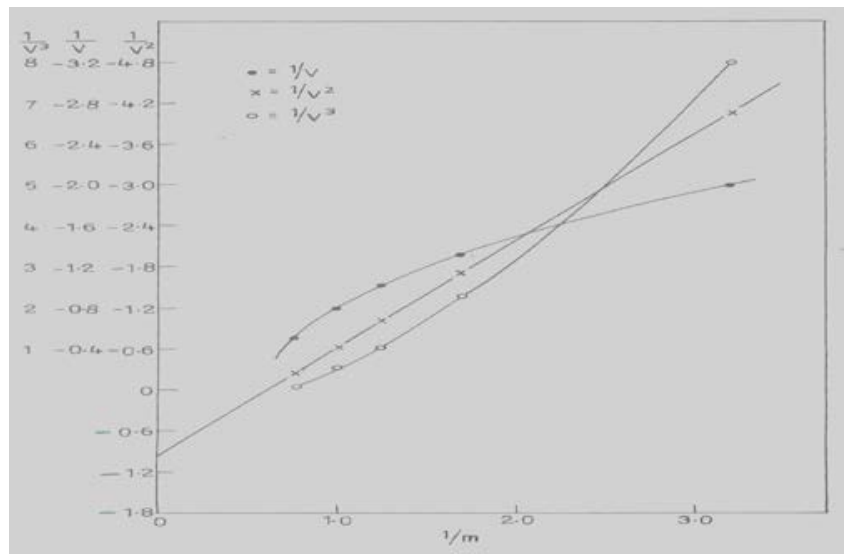

Figure 6. Asmus' method: $\mathrm{Ti}(\mathrm{IV})=1.0 \mathrm{~mL}$ of $1.0 \times 10^{-4} \mathrm{M}, 3,4-\mathrm{DHBINH}=1.0 \mathrm{~mL}$ of $1.0 \times 10^{-4} \mathrm{M}, \mathrm{pH}=3.5$ and $\lambda_{\max }=370 \mathrm{~nm}$

\section{Calculation of instability constant of Ti(IV)-3,4-DHBINH complex}

The instability constant of Ti(IV)-3,4-DHBINH was calculated by Asmus' method. The instability constant of Ti(IV)-3,4-DHBINH was calculated from the intercept value on the yaxis of Asmus method graph and by using the following equation: Intercept $=-\left[b_{c} / V\right]^{n} \cdot 1 / K_{c}$

Where $\mathrm{K}_{\mathrm{c}}=$ the instability constant of the complex, $\mathrm{b}_{\mathrm{c}}=$ concentration of the reagent, $\mathrm{V}=$ total volume of the final solution, The values of ' $\mathrm{n}$ ' and intercept are found to be 2 and -0.99 , respectively.

The instability constant of Ti(IV)-3,4-DHBINH complex was calculated and found to be $1.010 \times 10^{-10}$ at room temperature.

\section{Effect of foreign ions}

The effect of foreign ions on complexation was studied by taking $1.0 \mathrm{~mL}$ of Ti(IV) solution, $1.0 \mathrm{~mL}$ of required concentration of the foreign ion solution, $4.0 \mathrm{~mL}$ of sodium acetateacetic acid buffer (pH 3.5) and $2.0 \mathrm{~mL}$ of 3,4-DHBINH solution in a $10.0 \mathrm{~mL}$ standard flask. The total volume of the solution was brought to $10.0 \mathrm{~mL}$ with double distilled water. The experiment was repeated by changing the concentration of the diverse ion. The absorbances were measured at $370 \mathrm{~nm}$. A change of \pm 0.02 was taken as the tolerance limit for interference. The tolerance limit of $\mathrm{Mg}(\mathrm{II}), \mathrm{Ba}(\mathrm{II}), \mathrm{Mn}(\mathrm{II}), \mathrm{Fe}(\mathrm{III}), \mathrm{Ni}(\mathrm{II})$ and $\mathrm{Cu}(\mathrm{II})$ are 2500 ppm, 2300 ppm, 2000 ppm, 1500 ppm, 1200 ppm and 20 ppm, respectively. The tolerance limit of anions like ascorbic acid, thiocyanate, EDTA, thiourea, iodide, tartrate, oxalate and phosphate are 5000 ppm, 3500 ppm, 3000 ppm, 1600 ppm, 1050 ppm, 950 ppm, $500 \mathrm{ppm}$ and $500 \mathrm{ppm}$, respectively. The interference of $\mathrm{Cu}(\mathrm{II})$ and $\mathrm{Mo}(\mathrm{VI})$ could be suppressed by using $1.0 \mathrm{~mL}$ of $2 \%$ EDTA. The interference of $\mathrm{Pd}(\mathrm{II})$ could be suppressed by using $1.0 \mathrm{~mL}$ of $0.2 \%$ phosphate. The interference of $\mathrm{V}(\mathrm{V})$ and $\mathrm{Cr}(\mathrm{VI})$ could be suppressed by using $1.0 \mathrm{~mL}$ of $0.2 \%$ thiocyanate.

\section{Conclusion}

The rapidity of color development with 3,4-DHBINH is an advantage in analyzing various samples, in which titanium(IV) can vary over a wide range. When compared to the other existing $^{11-19}$ methods (Table 1). The developed method retains specific interaction of titanium(IV) with 3,4-DHBINH to form a colored complex and has good sensitivity at room 
temperature without the need of extraction. The uses of organic solvents which were generally toxic were avoided in this proposed method. The proposed method has significant advantage over the other spectrophotometric methods in terms of simplicity and sensitivity. This proposed method has good precision and accuracy.

Table 1. Comparison of the present method with other spectrophotometric methods for the determination of titanium(IV)

\begin{tabular}{|c|c|c|c|c|c|}
\hline 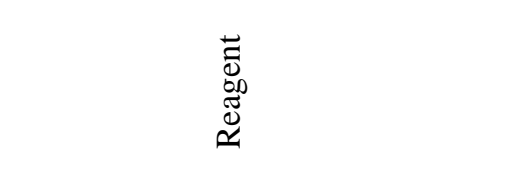 & 蔍 & 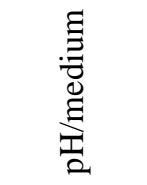 & 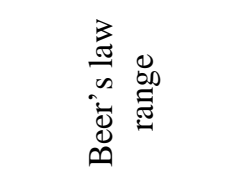 & 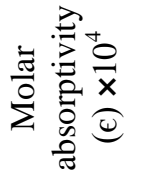 & 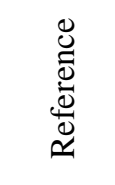 \\
\hline 3,4-DHBINH & 370 & 3.5 & 0.5-4.25 ppm & 1.49 & $\begin{array}{l}\text { Present } \\
\text { Method }\end{array}$ \\
\hline Salicylhydroxamic acid & 360 & 1.6 & $0.04-1.24 \mu \mathrm{g} / \mathrm{L}$ & 0.50 & 13 \\
\hline $\begin{array}{l}\mathrm{H}_{2} \mathrm{O}_{2} \text { and Methyethylene } \\
\text { diaminotrtraaceticacid (MEDTA) }\end{array}$ & 366 & 4.0 & $2-100 \mathrm{ng} / \mathrm{L}$ & 0.49 & 14 \\
\hline 2-hydroxy-1-acetonapthoneoxime & 397 & $9.5-10.0$ & 4-12 ppm & 0.25 & 15 \\
\hline Pyrocatechol and 2-aminopyridine & 400 & - & 5-100 ppm & 0.80 & 16 \\
\hline$m$-Chloroantipyrylazo and $\mathrm{H}_{2} \mathrm{O}_{2}$ & 615 & $3.0-3.7$ & $0.3 \mu \mathrm{g} / 25 \mathrm{~mL}$ & 19.00 & 17 \\
\hline 1-Hydroxy 2-acetonapthoneoxine & 375 & 9.0 & $0.0-80 \mathrm{ppm}$ & 1.10 & 18 \\
\hline Pyridoxal salicylal hydrazone & 450 & $0.9-2.5$ & $1.0-10.0 \mathrm{ppm}$ & 0.39 & 19 \\
\hline Pyridoxalnicotinoyl hydrazone & 410 & $2.1-2.3$ & - & 0.69 & 20 \\
\hline $\begin{array}{l}\text { 1,2-Cyclohexane dione } \\
\text { bis(benzoyl)-hydrazone }\end{array}$ & 477 & $1.75-3.0$ & - & 1.00 & 21 \\
\hline Gallacetophenoneoxime & 330 & - & - & 1.35 & 22 \\
\hline $\begin{array}{l}\text { 2-hydroxy-1-acetonaphtone } \\
\text { semicarbazone }\end{array}$ & 390 & 2.5 & $0 .-10 \mu \mathrm{g} / \mathrm{mL}$ & 0.29 & 23 \\
\hline $\begin{array}{l}\text { 2,4-dihydroxyacetophenone } \\
\text { isonicotinoylhydrazone }\end{array}$ & 490 & 1.5 & $\begin{array}{l}0.47-3.35 \\
\mu \mathrm{g} / \mathrm{mL}\end{array}$ & 1.00 & 24 \\
\hline $\begin{array}{l}\text { 2,4-dihydroxybenzaldehyde } \\
\text { isonicotinoylhydrazone }\end{array}$ & 500 & 1.5 & $\begin{array}{l}0.09-2.15 \\
\mu \mathrm{g} / \mathrm{mL}\end{array}$ & 1.35 & 25 \\
\hline $\begin{array}{l}\text { Diphenylglyoxalbis } \\
\text { (benzoylhydrazone) }\end{array}$ & 520 & 4.7 & ro & 0.08 & 26 \\
\hline $\begin{array}{l}\text { Orthovanillinisonicotinoyl } \\
\text { hydrazone }\end{array}$ & 450 & 2.0 & $2.0-10.0 \mu \mathrm{g} / \mathrm{mL}$ & 0.44 & 27 \\
\hline
\end{tabular}

\section{References}

1. http://en.wikipedia.org/wiki/Titanium

2. http://www.titaniuminfogroup.co.uk/

3. Andrey M C M, Galido Riado M D, Mufuz Leyva J A and Garcia-Vargas M, Anal Lett., 1993, 26, 2649.

4. Babiah O, Raveendra Reddy P, Krishna Reddy V and Sreenivasulu Reddy T, Indian J Chem., 1999, 38A, 1035.

5. Babiah O, Raveendra Reddy P, Krishna Reddy V and Sreenivasulu Reddy T, Indian J Chem., 2004, 81, 670.

6. Kesava Rao C, Krishna Reddy V and Sreenivasulu Reddy T, Talanta, 1994, 41, 237. 
7. Dolgorev A V, Zh Analit Khim., 1973, 28, 1093.

8. $\quad$ Podchainova V N and Dzyubo L N, Anal Abstr., 1973, 24, 99.

9. Sah P T and Peoplu S A, J An Pharm Assoc Sci Ed., 1954, 43, 513.

10. Vogel, A.I. A Text Book of Quantitative Inorganic Analysis, ELBS and Longmann, 1978, $4^{\text {th }}$ Edition, p.750.

11. Captain Vally, Ann Chin (Rome), 1989, 79, 509.

12. Castro-Romero J M, Fernandez-soils J H, Bollain Rodrignez, Moria H and BermejoMartinez F, Bol Soc Quim (Pero)., 1990, 56(4), 177 (Eng).

13. Abdulla R and Abbasia G A, Azerob Khim Zh, 1987, 2, 126.

14. Du, Hengkun, Lei and Yalin, Fenxi Hanxue, 1991, 19(3), 335(Ch).

15. Gallego M, Valcarcel M and Vargas M, Mikro Chim Acta., 1983, 1, 289.

16. Cejas M A, Gomez-Hens A and Valcarcel M, Quim Anal., 1984, 3, 164.

17. Garcia-Vargas M, Frvilla S and Milla M, Talanta, 1986, 33, 209.

18. Babaiah O, Kesava Rao C, Sreenivasulu Reddy T and Krishna Reddy V, Talanta, 1996, 43, 551.

19. Silva M, Gallego M and Valcarcel M, Talanta, 1980, 27, 615. 